\title{
Starch source and content in postpartum dairy cow diets: Effects on plasma metabolites and reproductive processes
}

\author{
B. L. Dyck, ${ }^{*}$ M. G. Colazo, $†$ D. J. Ambrose, ${ }^{*} \dagger$ M. K. Dyck, ${ }^{*}$ and L. Doepel ${ }^{\star 1,2}$ \\ *Department of Agricultural Food and Nutritional Science, University of Alberta, Edmonton, AB, Canada T6G 2P5 \\ †Alberta Agriculture and Rural Development, Edmonton, AB, Canada T6H 5T6
}

\begin{abstract}
The objective of this study was to examine the effects of dietary starch source and content in the immediate postpartum period on plasma metabolites and hormones and ovarian follicular development. One of 3 diets was fed in a randomized block design to 40 cows from calving until $70 \mathrm{~d}$ in milk. The diets contained $45 \%$ alfalfa silage (AS), $45 \%$ barley silage (BS), or $41 \%$ barley silage and $4 \%$ supplemental starch (SS) on a dry matter basis. All diets contained $45 \%$ barley-based concentrate and $10 \%$ alfalfa hay. Resulting starch levels were $25.2,23.3$, and $26.7 \%$ for AS, BS, and SS, respectively. Body condition was scored every other week and dry matter intake and milk yield were recorded daily. Milk samples were obtained weekly and blood samples were taken at calving and then every other week to determine concentrations of glucose, insulin, insulin-like growth factor- $1, \beta$-hydroxybutyrate, and nonesterified fatty acids. Transrectal ultrasonography was performed twice per week from $7 \mathrm{~d}$ after calving until first ovulation or $62 \mathrm{~d}$ in milk in all cows. For a subset of $7 \mathrm{AS}-$, 8 BS-, and 9 SS-fed cows, a complete estrous cycle was monitored for ovarian dynamics, and blood samples were collected every second day for progesterone and estradiol. Luteinizing hormone pulsatility was also determined (5 cows/treatment) approximately $15 \mathrm{~d}$ postcalving. Treatment had no effect on body condition score, dry matter intake, blood metabolites, milk yield, or milk fat and protein contents, but BS-fed cows had significantly higher levels of milk urea nitrogen compared with SS cows. Cows fed SS (31 d) tended to have a shorter interval from calving to first ovulation than cows fed AS (43 d) or BS (38 d). The incidence of double first ovulations was higher in cows fed SS (46\%) compared with those fed BS (0\%). Treatment had no effect on LH pulse frequency or amplitude, ovarian dynamics, or progesterone and estradiol concentrations
\end{abstract}

Received December 3, 2010.

Accepted April 25, 2011.

${ }^{1}$ Corresponding author: ldoepel@ucalgary.ca

${ }^{2}$ Current address: University of Calgary Faculty of Veterinary Medicine, 3280 Hospital Drive NW Calgary, AB, Canada T2N 4 Z6. during the observed estrous cycle. Energy balance did not differ among cows fed the 3 diets. Overall, dietary starch source and concentration had little effect on productivity or metabolic status of postpartum cows.

Key words: energy balance, starch, postpartum cow, ovulation

\section{INTRODUCTION}

Declining reproductive performance in postpartum dairy cows has been reported since the mid 1970s (Butler and Smith, 1989). While genetic selection has focused on increasing milk yield, an inverse relationship between milk production and reproductive performance postpartum has been proposed (Lucy, 2001). High milk yield is also associated with negative energy balance (NEB) in the immediate postpartum period (Butler, 2000; Doepel et al., 2002). Negative energy balance has been identified as a risk factor for delay in first ovulation postpartum (Butler and Smith, 1989) and this delay has been negatively correlated with conception rate (Butler, 2000).

Insulin and IGF-1 have been shown to play a critical role in follicular cell proliferation and steroidogenesis in vitro (Spicer and Echternkamp, 1995), and increased circulating concentrations have been positively associated with ovulation rates and follicular growth in vivo (Armstrong et al., 2001, 2003). Plasma concentrations of both insulin and IGF-1 generally decline postcalving (Beam and Butler, 1999), and this decline is associated with a more severe NEB and an increase in the number of days to first ovulation (Gong et al., 2002). Plasma concentrations of insulin and IGF-1 can be augmented by increasing the inclusion of NSC in the diet (Armstrong et al., 2001).

Nonstructural carbohydrates, primarily starch, are typically increased through the inclusion of grain in the diet, but can also be increased by feeding cereal silage in place of legume silage. Mustafa et al. (2000) reported that barley silage contained $14.5 \%$ starch, whereas alfalfa silage contained only $0.6 \%$ starch. The objective of this study was to examine the effects of starch source (primarily concentrate vs. concentrate + silage) and dietary starch content (with or without supplemental 
starch) in the immediate postpartum period on plasma energy substrates and hormones involved in energy metabolism, and ovarian follicular development. Production parameters, including milk yield and composition, DMI, and BCS were also evaluated. We hypothesized that increased dietary starch content would improve energy balance (EB) and cow productivity, increase the concentrations of IGF-1 and insulin, and decrease days to first ovulation postpartum.

\section{MATERIALS AND METHODS}

\section{Animals and Treatments}

Animals were cared for according to the guidelines of the Canadian Council on Animal Care (1993) and all procedures conducted with animals were approved by the University of Alberta Livestock Animal Care and Use Committee. Seventeen primiparous and 24 multiparous Holstein cows were initially used for this study, but 1 primiparous cow was subsequently removed from the trial (d 20) due to poor temperament, thus the data from 40 cows were analyzed. Cows were housed in a tiestall barn, were let out for exercise for approximately $2 \mathrm{~h}$ every morning, and had unlimited access to water.

Cows were blocked by parity, with the multiparous cows also blocked by milk yield in their previous lactation, and randomly assigned within block to 1 of 3 dietary treatments: alfalfa silage (AS, $\mathrm{n}=13)$, barley silage $(\mathbf{B S}, \mathrm{n}=14)$, or barley silage $+\operatorname{starch}(\mathbf{S S}, \mathrm{n}=$ 13). The SS treatment was the same as the BS treatment except that $4 \%$ barley silage on a DM basis was replaced with $4 \%$ corn starch (Melojel, Quadra Chemicals, Edmonton, AB, Canada). The AS and BS diets were formulated to meet the nutrient requirements of a 650-kg cow producing $40 \mathrm{~kg}$ of milk/d (NRC, 2001). Ingredient and nutrient composition of the diets is presented in Table 1 . The alfalfa silage and barley silage contained $1.6 \%$ and $12.1 \%$ starch, respectively, whereas the concentrate mix used for the AS diet contained $54 \%$ starch and that used for the BS and SS diets contained $39 \%$ starch. Cows were assigned to the experimental diets immediately after calving and remained on their respective diets until 70 DIM. They were fed the diets ad libitum as a TMR once daily at $0800 \mathrm{~h}$, allowing for $10 \%$ orts.

Cows were milked twice daily at 0400 and $1500 \mathrm{~h}$ and yields were recorded daily. Milk samples (a.m. and p.m.) were collected weekly from $7 \mathrm{~d}$ after calving until 70 DIM. Cows were scored for body condition at calving and every other week thereafter until 70 DIM. Body condition score was determined by one technician blinded to the dietary treatments using the scale of 1 (emaciated) to 5 (overconditioned; Edmonson et al.,
1989). Net energy balance was determined for each cow on a weekly basis for overall EB and daily for days to reach the $\mathrm{EB}$ nadir. The net energy requirement included that for maintenance: Mcal $/ \mathrm{d}=0.08 \times \mathrm{kg}$ of $\mathrm{BW}^{0.75}$, and for milk: Mcal $/ \mathrm{d}=$ milk yield $\times[(0.0929$ $\times$ fat $\%)+(0.0547 \times$ protein $\%)+(0.0395 \times$ lactose $\%)$ ] (NRC, 2001). For first-lactation cows, net energy for growth (NRC, 2001) also constituted part of the energy requirement.

\section{Sampling}

To determine individual cow DMI, the amounts of feed offered and refused were weighed and recorded daily. Silage DM was determined weekly and used to maintain the formulated DM composition of the diet. Ingredient samples were collected weekly and composited monthly for analysis of DM, OM, CP, NDF, ADF, lignin, and starch. Orts from each cow were collected weekly for DM determination.

Twenty milliliters of blood was collected from each cow within $24 \mathrm{~h}$ of calving and on d 7, 14, 28, 42, 56, and 70 postpartum from the coccygeal vein or artery using evacuated Vacutainer tubes containing sodium heparin (Becton Dickinson and Co., Franklin Lakes, NJ). Blood was collected $2 \mathrm{~h}$ after feeding to avoid potential postprandial effects on plasma hormone and metabolite concentrations. A subset of cows $(\mathrm{n}=15)$ was used to determine LH pulsatility at approximately $15 \mathrm{~d}$ postpartum. Five cows per treatment were catheterized in the jugular vein (Zalkovic et al., 2001) on the day of collection and $10 \mathrm{~mL}$ of blood was collected every 15 min from 0900 to $1700 \mathrm{~h}$. All blood samples were immediately placed on ice and centrifuged at 3,000 $\times g$ for $25 \mathrm{~min}$ at $4^{\circ} \mathrm{C}$ within $1 \mathrm{~h}$ of collection, and plasma was harvested and frozen at $-20^{\circ} \mathrm{C}$ until further analysis. Blood samples were also collected every second day throughout the observed estrous cycle, as explained in the Ultrasonography section, to determine estradiol and progesterone concentrations.

\section{Ultrasonography}

Transrectal ultrasonography (Aloka-500V scanner equipped with a 7.5-MHz linear transducer, Aloka Co., Tokyo, Japan) was performed twice weekly from $7 \pm 1$ $\mathrm{d}$ after calving until the first ovulation or until 62 DIM to determine the approximate interval from calving to ovulation. An ovulation was presumed if the dominant follicle observed in the previous scanning was replaced by a corpus luteum $(\mathbf{C L})$. One complete estrous cycle was monitored for ovarian dynamics in $7 \mathrm{AS}, 8 \mathrm{BS}$, and 9 SS cows that had ovulated before 45 DIM. Prior to the monitoring of the estrous cycle, cows were given 500 
Table 1. Ingredient and nutrient composition of the dietary treatments

\begin{tabular}{|c|c|c|c|}
\hline \multirow[b]{2}{*}{ Item } & \multicolumn{3}{|c|}{ Diet $^{1}$} \\
\hline & AS & BS & SS \\
\hline \multicolumn{4}{|c|}{ Ingredient composition, $\%$ of $\mathrm{DM}$} \\
\hline Alfalfa silage & 44.7 & - & - \\
\hline Barley silage & - & 44.6 & 40.6 \\
\hline Alfalfa hay & 10.0 & 10.0 & 10.1 \\
\hline Corn starch ${ }^{2}$ & - & - & 4.0 \\
\hline Corn & 25.4 & 20.3 & 20.3 \\
\hline Barley & 10.2 & 4.8 & 4.8 \\
\hline Canola meal & - & 6.7 & 6.7 \\
\hline Soybean meal & 2.5 & 6.7 & 6.7 \\
\hline Corn gluten meal & 3.9 & 2.9 & 2.9 \\
\hline Rumen-protected fat ${ }^{3}$ & 0.5 & 0.5 & 0.5 \\
\hline Pork fat & 1.0 & 1.0 & 1.0 \\
\hline Limestone & 0.2 & 0.2 & 0.2 \\
\hline Magnesium oxide & 0.1 & 0.1 & 0.1 \\
\hline Salt & 0.2 & 0.2 & 0.2 \\
\hline Dicalcium phosphate & 0.5 & 0.5 & 0.5 \\
\hline Vitamins/minerals ${ }^{4}$ & 1.5 & 1.5 & 1.5 \\
\hline \multicolumn{4}{|c|}{ Nutrient composition, \% of DM } \\
\hline DM & 66.5 & 65.8 & 67.9 \\
\hline $\mathrm{OM}$ & 92.4 & 93.2 & 89.7 \\
\hline $\mathrm{NDF}$ & 25.8 & 30.9 & 28.8 \\
\hline $\mathrm{ADF}$ & 16.8 & 17.7 & 16.6 \\
\hline Lignin & 4.1 & 2.9 & 2.8 \\
\hline $\mathrm{CP}$ & 17.1 & 18.8 & 18.4 \\
\hline Starch $^{5}$ & 25.2 & 23.3 & 26.7 \\
\hline $\mathrm{NE}_{\mathrm{L}},{ }^{6} \mathrm{Mcal} / \mathrm{kg}$ of $\mathrm{DM}$ & 1.65 & 1.71 & 1.73 \\
\hline \multirow{2}{*}{\multicolumn{4}{|c|}{${ }^{1} \mathrm{AS}=$ alfalfa silage diet; $\mathrm{BS}=$ barley silage diet; and $\mathrm{SS}=$ barley silage $+4 \%$ starch diet. }} \\
\hline & \multicolumn{3}{|c|}{${ }^{2}$ Melojel, Quadra Chemicals, Edmonton, AB. } \\
\hline \multicolumn{4}{|c|}{${ }^{3}$ Megalac, Church \& Dwight Co. Inc., Princeton, NJ. } \\
\hline \multicolumn{4}{|c|}{$\begin{array}{l}{ }^{4} \text { Supplied the diet with } 2.2 \mathrm{mg} / \mathrm{kg} \text { of Co, } 80.1 \mathrm{mg} / \mathrm{kg} \text { of Cu, } 3.3 \mathrm{mg} / \mathrm{kg} \text { of I, } 142.1 \mathrm{mg} / \mathrm{kg} \text { of Mn, } 0.65 \mathrm{mg} / \mathrm{kg} \text { of } \\
\text { Se, } 239.1 \mathrm{mg} / \mathrm{kg} \text { of } \mathrm{Zn}, 16.2 \mathrm{kIU} / \mathrm{kg} \text { of vitamin A, } 3.22 \mathrm{kIU} / \mathrm{kg} \text { of vitamin } \mathrm{D}_{3}, 114.7 \mathrm{IU} / \mathrm{kg} \text { of vitamin E, and } \\
1.4 \mathrm{mg} / \mathrm{kg} \text { of biotin. }\end{array}$} \\
\hline \multicolumn{4}{|c|}{${ }^{5}$ Starch levels were significantly different from one another $(P \leq 0.05 ; \mathrm{SEM}=0.34)$} \\
\hline${ }^{6}$ Calculated using NRC & $0 \mathrm{~kg} / \mathrm{d}$ & & \\
\hline
\end{tabular}

$\mu \mathrm{g}$ of cloprostenol (PGF; Estrumate, Schering-Plough Animal Health, Pointe-Claire, QC, Canada) to regress the CL, and ovaries were then monitored once daily by ultrasonography to determine ovulation and thus the beginning of a new estrous cycle. After ovulation, ovarian follicular and CL dynamics were monitored by ultrasonography every second day throughout the cycle until the subsequent ovulation. The diameter and location of follicles and CL were recorded as described by Pierson and Ginther (1984). A timeline of the main experimental events is presented in Figure 1.

\section{Laboratory Analyses}

Milk samples were preserved with $1.5 \mathrm{mg}$ of 2-bromo-2-nitropropane-1,3-diol and $0.7 \mathrm{mg}$ of Pimaricin (Brotab 10, Systems Plus, Baden, ON, Canada) and analyzed for fat, protein, lactose, and MUN by infrared spectroscopy (MilkoScan 605, Foss Electric, Hillerød, Denmark) at Canwest Central Milk Testing Laboratory (Edmonton, AB, Canada).
Dry matter content of feed ingredients and orts was determined by drying samples at $55^{\circ} \mathrm{C}$ in a forced air oven for 48 h. Silage, hay, and concentrate samples were ground in a Wiley mill (Arthur H. Thomas Co., Philadelphia, PA) to pass through a 1-mm screen. Neutral detergent fiber, $\mathrm{ADF}$, and lignin were determined using amylase and sodium sulfite on an Ankom ${ }^{2000}$ fiber analyzer (Ankom Technology, Macedon, NY) following the procedures of Van Soest et al. (1991). Organic matter was determined by ashing at $550^{\circ} \mathrm{C}$ for $5 \mathrm{~h}$. Nitrogen concentration was determined on a Leco carbon/nitrogen determinator (TruSpec CN, Leco, St. Joseph, $\mathrm{MI}$ ) and $\mathrm{CP}$ calculated as $\mathrm{N} \times 6.25$. Starch content was measured using an enzymatic method as reported by Silveira et al. (2007). Briefly, samples were gelatinized with sodium hydroxide and the resulting glucose measured with a glucose oxidase/peroxidase enzyme (\#P7119, Sigma, St. Louis, MO) and dihydrochloride (\#F5803, Sigma).

A commercial kit was used to analyze NEFA [NEFAHR (2), Wako Chemicals USA, Richmond, VA], and 


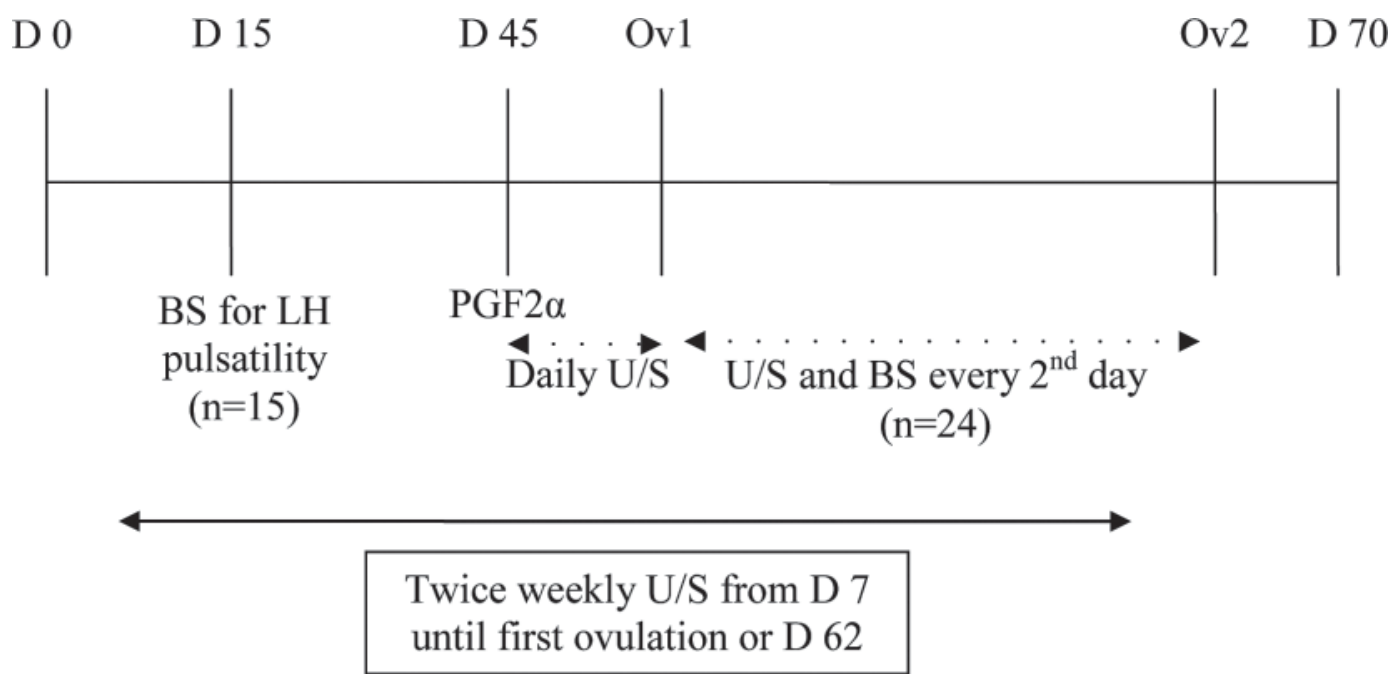

Figure 1. Schematic representation of the sampling timeline for reproductive performance measures. Ultrasonography was performed twice weekly beginning on $\mathrm{d} 7$ until the first ovulation was observed or until d 62 . On d 15, a subset of 15 cows was used to determine LH pulsatility; blood samples were collected every 15 min for $8 \mathrm{~h}$. Prostaglandin $\mathrm{F}_{2 \alpha}$ was given on d 45 to regress the corpus luteum in a subset of 24 cows and then ultrasonography $(\mathrm{U} / \mathrm{S})$ was performed daily to observe the initiation of a cycle. In this same subset, ultrasonography was performed and blood samples (BS) were taken every second day until the subsequent ovulation to determine estradiol and progesterone levels. Ov1 = initiation of the observed cycle; Ov2 = termination of the observed cycle.

BHBA was determined by the procedure of Williamson and Mellanby (1974) adapted to a 96-well microtiter plate format. A colorimetric assay (Raabo and Terkildsen, 1960) using a glucose oxidase/peroxidase enzyme (Sigma \#P7119) and dihydrochloride (Sigma \#F5803) was used to measure the concentration of plasma glucose. A solid-phase RIA kit was used to determine concentrations of plasma insulin (Coat-A-Count, Diagnostic Products Corp., Los Angeles, CA). Intra- and interassay CV were 8.0 and $19.9 \%$, respectively, and the assay sensitivity was $1.3 \mathrm{IU} / \mathrm{mL}$. Insulin-like growth factor-1 was determined as described by Novak et al. (2002) with the following modification: IGF-1 used for iodination and the reference standard was GroPep Receptor grade human IGF-1 (GroPep \#CU100, GroPep Ltd., Adelaide, Australia). The intra- and interassay CV were 5.9 and $26.0 \%$, respectively, and the average assay sensitivity was $5.2 \mathrm{ng} / \mathrm{mL}$. A solid-phase RIA kit was used for progesterone determination (Coat-A-Count, Diagnostic Products Corp.). The intra- and interassay CV were 2.9 and $7.4 \%$, respectively, and the average sensitivity was $0.1 \mathrm{ng} / \mathrm{mL}$. Estradiol was determined using the method reported by Martínez et al. (2005). Samples were analyzed in 2 assays with intraassay CV being 10.2 and $1.5 \%$ for low reference sera and 5.9 and $0.6 \%$ for high reference sera. The interassay CV was $8.2 \%$ for low reference sera and $5.5 \%$ for high reference sera with a sensitivity of $1.0 \mathrm{ng} / \mathrm{mL}$.

Luteinizing hormone concentrations were determined by a previously validated, double-antibody RIA (Rawlings and Evans, 1995). Samples were analyzed in one assay, with the intraassay CV being $4.1 \%$ with a sensitivity of $0.1 \mathrm{ng} / \mathrm{mL}$. The number of LH pulses during the 8-h sampling period was determined by taking the overall LH mean concentration and then adding 1 standard deviation. Any value above this was considered a pulse. As well, LH amplitude was determined by taking the concentration of LH from the baseline to the top of the peak (Goodman and Karsch, 1980).

\section{Statistical Analyses}

Data on energy balance, milk yield and composition, and DMI were not used for the first 2 wk postpartum for $1 \mathrm{BS}$ and $1 \mathrm{SS}$ cow due to early lactation metabolic conditions. Prior to statistical analysis, DMI, milk yield, and composition data were reduced to weekly means. Repeated measures in the MIXED procedure of SAS (version 9.1; SAS Institute Inc., Cary, NC) were used to analyze DMI, milk yield, milk composition, BCS, plasma metabolite and hormone concentration data, as well as insulin, IGF-1, glucose, BHBA, and NEFA data. The statistical model included block, treatment, time (week or DIM), and treatment $\times$ week interaction as fixed effects. The repeated measure was time and the model was tested using cow as the subject term. The covariance structure resulting in the lowest Bayesian information criterion indicated best fit.

The repeated measures option in the MIXED procedure of SAS as described above was used to analyze progesterone concentrations from d 0 to 14 of the estrous cycle and estradiol concentrations on d 4, 6, 
and 8 of the cycle and then the last 5 samples before ovulation. For example, if ovulation happened on $\mathrm{d}$ 24 , then estradiol concentrations were measured on $\mathrm{d}$ $16,18,20,22$, and 24. All single measurement data (e.g., length of estrous cycle, size of preovulatory follicle) were analyzed using the MIXED procedure in SAS with treatment and block as fixed effects in the model. A survival analysis (LIFETEST procedure) was performed to obtain a crude estimate of the effect of treatment on interval (d) from calving to first ovulation postpartum data. Number of double first ovulations and number of cows not ovulating before 62 DIM were analyzed using Chi-squared analysis. Pearson correlation coefficients were calculated in SAS between follicle size at first ultrasonography after calving, interval (d) from calving to reach a dominant follicle (DDF) of $\geq 10 \mathrm{~mm}$, interval (d) from calving to first ovulation, BCS at 28 DIM, and LH peaks, amplitude, and mean. Orthogonal contrasts were used to determine the effects of treatment. A "source" contrast determined the effect of starch source; that is, AS versus the mean of BS and SS. A "level" contrast was used to determine the effect of the added starch, and compared BS to SS. All data are reported as least squares means with pooled standard errors, and significance was declared at $P \leq 0.05$.

\section{RESULTS}

\section{Diet and Production Parameters}

The diets were formulated to contain $18.5 \% \mathrm{CP}$ on a DM basis. However, because the $\mathrm{CP}$ content of the alfalfa silage was lower than analyzed before the study, the CP content of the AS diet was only $17 \%$. In addition, the NDF content of the BS and SS diets was higher than formulated. Forage contributed 24 and 19\% of the total starch in the BS and SS diets, respectively, but only $3.5 \%$ in the AS diet. The TMR were analyzed for starch content before the initiation of the study; the BS treatment contained $26.5 \%$ starch and thus starch addition was limited to $4 \%$ so that the total starch content would not exceed the recommended maximum of $30 \%$ (Grant, 2005). The TMR throughout the study averaged 25.2, 23.3, and $26.7 \%$ starch for AS, BS, and SS, respectively $(P<0.05)$.

Dietary treatment had no effect on DMI, which averaged $19 \mathrm{~kg} / \mathrm{d}$ across diets, or milk yield, which averaged $36.6 \mathrm{~kg} / \mathrm{d}$ (Table 2). Neither milk fat nor protein content was affected by treatment, but lactose concentration was lower $(P=0.02)$ for SS-fed cows than for BS-fed cows (Table 2). Milk fat, protein, and lactose yields were not different among treatments. Milk urea nitrogen concentration tended to be lower $(P=0.07)$ for AS-fed cows compared with the mean of BS- and SS-fed cows, and was lower $(P<0.01)$ for cows on SS compared with those on BS.

Overall BCS and the change in BCS from d 0 to 70 were not affected by treatment, with cows having an average BCS of 3.0 and losing 0.54 BCS units over the course of the study (Table 2). Net EB was less negative for AS cows compared with the mean of BS and SS cows $(P=0.05)$, but was not different between BS and SS cows $(P=0.73$; Table 2, Figure 2). Days to reach EB nadir were not affected by treatment (Table 2) and averaged $12.6 \mathrm{~d}$ postpartum. Cows remained

Table 2. Effect of dietary starch concentration on production parameters

\begin{tabular}{|c|c|c|c|c|c|c|}
\hline \multirow[b]{2}{*}{ Item } & \multicolumn{3}{|c|}{ Treatment $^{1}$} & \multirow[b]{2}{*}{ SEM } & \multicolumn{2}{|c|}{$P$-value contrast ${ }^{2}$} \\
\hline & $\mathrm{AS}$ & $\mathrm{BS}$ & SS & & Source & Level \\
\hline Number & 13 & 14 & 13 & & & \\
\hline DMI, $\mathrm{kg} / \mathrm{d}$ & 19.5 & 18.4 & 19.1 & 0.64 & 0.31 & 0.43 \\
\hline $\mathrm{BCS}$ & 2.94 & 3.03 & 3.03 & 0.05 & 0.18 & 0.94 \\
\hline Change in $\mathrm{BCS}^{3}$ & -0.60 & -0.57 & -0.46 & 0.06 & 0.21 & 0.12 \\
\hline Energy balance (EB), Mcal/d & -1.48 & -3.58 & -3.20 & 0.79 & 0.05 & 0.73 \\
\hline $\begin{array}{l}\text { Time to reach negative EB nadir, } d \\
\text { Yield }\end{array}$ & \multicolumn{5}{|c|}{ Yield } & 0.18 \\
\hline Milk, $\mathrm{kg} / \mathrm{d}$ & 35.7 & 35.8 & 38.3 & 1.67 & 0.49 & 0.29 \\
\hline Fat, $\mathrm{g} / \mathrm{d}$ & 1,296 & 1,341 & 1,359 & 57.1 & 0.44 & 0.82 \\
\hline Protein, g/d & 1,043 & 1,078 & 1,144 & 43.7 & 0.21 & 0.28 \\
\hline Lactose, $\mathrm{g} / \mathrm{d}$ & 1,657 & 1,669 & 1,735 & 78.9 & 0.65 & 0.55 \\
\hline \multicolumn{7}{|l|}{ Milk composition } \\
\hline Fat, $\%$ & 3.67 & 3.80 & 3.64 & 0.14 & 0.78 & 0.43 \\
\hline Protein, $\%$ & 2.93 & 3.03 & 3.07 & 0.07 & 0.19 & 0.63 \\
\hline Lactose, \% & 4.65 & 4.67 & 4.53 & 0.04 & 0.27 & 0.02 \\
\hline MUN, mg/dL & 13.8 & 16.3 & 13.8 & 0.56 & 0.07 & 0.004 \\
\hline
\end{tabular}


Table 3. Effect of dietary starch source and concentration on plasma hormone and metabolite concentrations

\begin{tabular}{|c|c|c|c|c|c|c|}
\hline \multirow[b]{2}{*}{ Item } & \multicolumn{3}{|c|}{ Treatment $^{1}$} & \multirow[b]{2}{*}{ SEM } & \multicolumn{2}{|c|}{$P$-value contrast ${ }^{2}$} \\
\hline & $\mathrm{AS}$ & $\mathrm{BS}$ & SS & & Source & Level \\
\hline Number & 13 & 14 & 13 & & & \\
\hline Glucose, $\mathrm{mg} / \mathrm{dL}$ & 59.4 & 59.3 & 58.0 & 1.52 & 0.70 & 0.57 \\
\hline Insulin, $\mu \mathrm{IU} / \mathrm{mL}$ & 6.52 & 6.51 & 6.92 & 0.80 & 0.84 & 0.72 \\
\hline $\mathrm{IGF}-1, \mathrm{ng} / \mathrm{mL}$ & 51.8 & 55.8 & 52.3 & 3.43 & 0.59 & 0.46 \\
\hline NEFA, mEq/L & 356.9 & 296.3 & 287.4 & 30.78 & 0.09 & 0.83 \\
\hline $\mathrm{BHBA}, \mathrm{mg} / \mathrm{dL}$ & 7.99 & 8.62 & 9.08 & 0.37 & 0.07 & 0.36 \\
\hline
\end{tabular}

${ }^{1} \mathrm{AS}=$ alfalfa silage diet; $\mathrm{BS}=$ barley silage diet; and $\mathrm{SS}=$ barley silage $+4 \%$ starch diet.

${ }^{2} P$-value contrast: source $=\mathrm{AS}$ vs. the mean of BS and SS; level $=\mathrm{BS}$ vs. SS.

in a state of NEB for the first 7 wk postpartum, with cows on AS being the first to reach positive EB (Figure 2).

\section{Blood Metabolites}

No treatment or time $\times$ treatment effects were observed for any of the hormones or metabolites measured (Table 3), except that NEFA concentration tended $(P$ $=0.09)$ to be higher for cows fed $\mathrm{AS}(357 \mathrm{mEq} / \mathrm{L})$ than for cows fed BS and SS $(292 \mathrm{mEq} / \mathrm{L})$. With the exception of IGF-1, a time effect was observed for all of the measured parameters $(P<0.01)$. Glucose concentration decreased from calving to $7 \mathrm{~d}$ postpartum and then began to slowly increase thereafter $(P<0.001)$, whereas NEFA concentration was highest at calving and declined thereafter (Figure 3). Insulin concentration decreased from $7.8 \mu \mathrm{IU} / \mathrm{mL}$ at calving to $4.5 \mu \mathrm{IU} /$

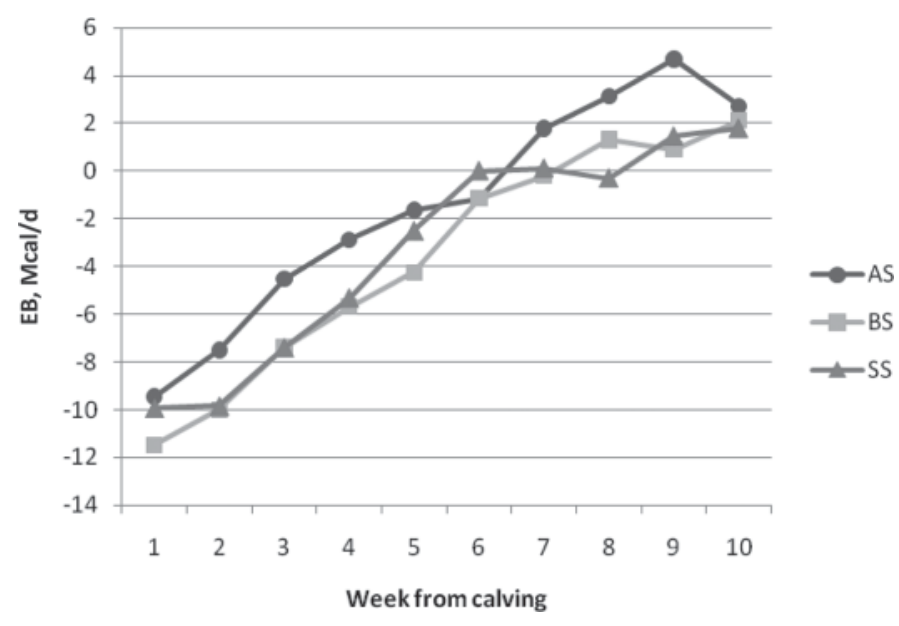

Figure 2. Energy balance (EB) of cows fed different starch sources and content. Cows were fed an alfalfa silage diet (AS), a barley silage diet (BS), or a BS $+4 \%$ added starch diet (SS) from calving until 70 DIM. Energy balance was affected by time $(P<0.001)$ and was less negative for cows receiving AS than for those receiving BS and SS $(P$ $=0.05)$.
$\mathrm{mL}$ by $7 \mathrm{DIM}$ and then gradually increased to $9.6 \mu \mathrm{IU} /$ $\mathrm{mL}$ by 70 DIM.

\section{Reproductive Parameters}

Ultrasonography to First Ovulation. At the first ultrasound scanning of the ovaries $(7 \pm 1 \mathrm{~d}$ postpartum), the mean diameter of the largest follicle observed on either ovary was $6.5 \pm 0.8 \mathrm{~mm}$ and was not different among treatments (Table 4). Similarly, DDF of $\geq 10$ $\mathrm{mm}$ was not affected by treatment and averaged $11.9 \pm$ $1.4 \mathrm{~d}$. A negative correlation was observed between the follicle size at first ultrasonography and DDF of $\geq 10$ $\mathrm{mm}(\mathrm{r}=-0.76, P<0.001)$. The interval from calving to first ovulation postpartum was shorter for cows fed SS than for cows fed AS or BS $(P<0.05$; Table 4$)$. Interval from calving to first ovulation was positively correlated with $\mathrm{DDF} \geq 10 \mathrm{~mm}(\mathrm{r}=0.39, P<0.05)$ and

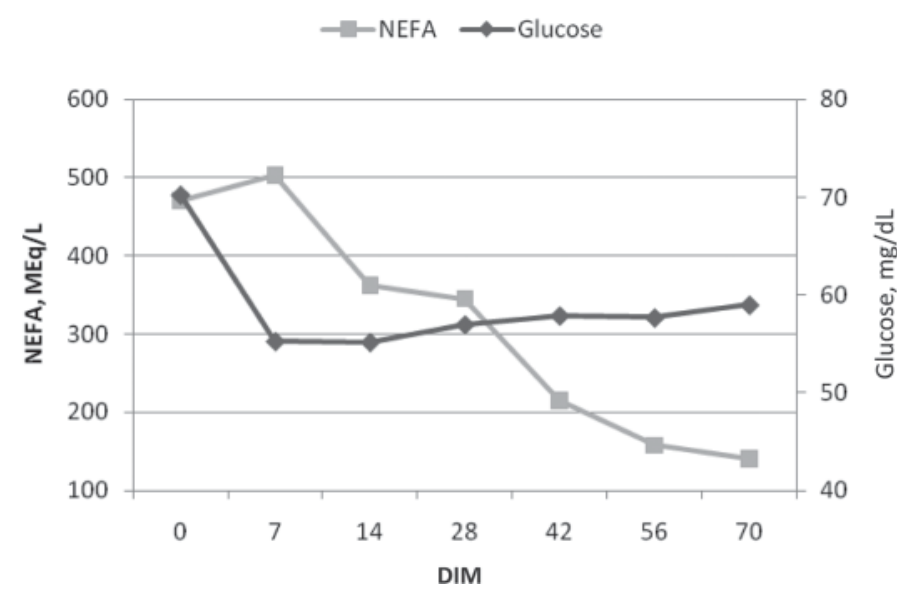

Figure 3. Plasma NEFA and glucose concentrations until 70 DIM. Cows were fed an alfalfa silage diet (AS), a barley silage diet (BS), or a BS $+4 \%$ added starch diet (SS) from calving until 70 DIM. No treatment effects $(P>0.10)$ were observed, but there was an effect of time $(P<0.01)$. 
DYCK ET AL.

Table 4. Effect of dietary starch concentration on follicular parameters, LH profile, and ovulation

\begin{tabular}{|c|c|c|c|c|c|c|}
\hline \multirow[b]{2}{*}{ Item } & \multicolumn{3}{|c|}{ Treatment $^{1}$} & \multirow[b]{2}{*}{ SEM } & \multicolumn{2}{|c|}{$P$-value contrast ${ }^{2}$} \\
\hline & AS & BS & SS & & Source & Level \\
\hline Number & 13 & 14 & 13 & & & \\
\hline Follicle diameter on $\mathrm{d} 7$ postpartum, $\mathrm{mm}$ & 6.9 & 6.2 & 6.5 & 0.8 & 0.6 & 0.8 \\
\hline $\mathrm{DDF} \geq 10 \mathrm{~mm}$ in diameter ${ }^{3}$ & 12.5 & 12.4 & 11.1 & 1.1 & 0.6 & 0.4 \\
\hline $\mathrm{LH}$ mean, $\mathrm{ng} / \mathrm{mL}$ & 0.4 & 0.5 & 0.5 & 0.1 & 0.7 & 0.8 \\
\hline LH peaks, no. & 2.0 & 2.6 & 3.2 & 0.4 & 0.1 & 0.3 \\
\hline LH amplitude, ng/mL & 1.3 & 1.4 & 1.1 & 0.3 & 0.9 & 0.5 \\
\hline Interval from calving to first ovulation, $\mathrm{d}$ & 43.2 & 38.1 & 30.6 & 3.9 & 0.2 & 0.09 \\
\hline Double first ovulations, no. (\%) & $4(31)$ & $0(0)$ & $6(46)$ & & 0.6 & 0.01 \\
\hline Cows not ovulating before 62 DIM, no. $(\%)$ & $2(15)$ & $3(21)$ & $0(0)$ & & 0.7 & 0.07 \\
\hline
\end{tabular}

negatively correlated with BCS at 28 DIM $(\mathrm{r}=-0.37$, $P<0.05)$. A significant treatment effect was observed for those cows having a double first ovulation postpartum. None of the BS-fed cows had a double ovulation compared with 4 on the AS diet and 6 on the SS diet $(P$ $<0.05$; Table 4). Treatment also tended to affect the number of cows not ovulating before 62 DIM, with all of the SS cows ovulating before 62 DIM, and 3 BS cows not ovulating by 62 DIM $(P=0.07$; Table 4$)$.

$\boldsymbol{L H} \boldsymbol{P u l s a t i l i t y . ~ N o ~ t r e a t m e n t ~ e f f e c t s ~ w e r e ~ o b s e r v e d ~}$ for mean plasma LH concentration $(0.47 \mathrm{ng} / \mathrm{mL})$, number of LH pulses (2.6), or pulse amplitude (1.3 ng/ $\mathrm{mL}$; Table 4). A positive correlation existed between follicle size at first ultrasonography and number of LH pulses $(\mathrm{r}=0.45, P=0.09)$ and a negative correlation between DDF of $\geq 10 \mathrm{~mm}$ and number of LH pulses ( $\mathrm{r}=-0.67, P<0.05)$. Interval from calving to first ovulation tended to be negatively correlated with the number of LH pulses $(\mathrm{r}=-0.52, P=0.06)$ and with mean LH concentration $(\mathrm{r}=-0.46, P=0.09)$.

Monitoring of Estrous Cycle. The number of follicular waves was not affected by treatment and av- eraged 2.5 (Table 5). Estrous cycle length was not different between treatments, nor was the diameter of the largest follicle observed during the first follicular wave (Table 5). The preovulatory follicle diameter averaged $16.1 \pm 0.8 \mathrm{~mm}$. Estradiol concentrations during the first follicular wave $(6.6 \mathrm{pg} / \mathrm{mL})$ and the preovulatory follicular wave $(6.1 \mathrm{pg} / \mathrm{mL})$ were not different among treatments (Table 5$)$. No treatment effects $(P>0.05)$ were observed for progesterone concentration during the first $14 \mathrm{~d}$ of the cycle (Table 5).

\section{DISCUSSION}

\section{Production and Metabolic Data}

In the present study, milk yield was not affected by dietary treatment, likely because of the similarity in DM and energy intake among the 3 groups of cows. Gong et al. (2002) also reported no change in milk yield after feeding a high starch diet (260 g of starch per $\mathrm{kg}$ of DM vs. $100 \mathrm{~g}$ of starch per $\mathrm{kg}$ of DM) but DMI was not reported. On the contrary, when Knowlton et al.

Table 5. Effect of dietary starch concentration on estrous cycle parameters

\begin{tabular}{|c|c|c|c|c|c|c|}
\hline \multirow[b]{2}{*}{ Item } & \multicolumn{3}{|c|}{ Treatment $^{1}$} & \multirow[b]{2}{*}{ SEM } & \multicolumn{2}{|c|}{$P$-value contrast ${ }^{2}$} \\
\hline & AS & BS & SS & & Source & Level \\
\hline Number & 7 & 8 & 9 & & & \\
\hline Follicular waves, no. & 2.4 & 2.3 & 2.7 & 0.3 & 0.7 & 0.3 \\
\hline Length of cycle, d & 23.8 & 23.8 & 25.6 & 2.6 & 0.8 & 0.6 \\
\hline Diameter of first dominant follicle, $\mathrm{mm}$ & 17.3 & 17.8 & 18.0 & 0.8 & 0.6 & 0.8 \\
\hline Preovulatory follicle size, $\mathrm{mm}$ & 15.5 & 16.2 & 16.7 & 1.0 & 0.5 & 0.7 \\
\hline Mean plasma estradiol during first follicular wave, $\mathrm{pg} / \mathrm{mL}^{3}$ & 6.8 & 6.3 & 6.8 & 1.4 & 0.9 & 0.8 \\
\hline Mean plasma estradiol during preovulatory follicle growth, $\mathrm{pg} / \mathrm{mL}^{4}$ & 4.7 & 6.1 & 7.6 & 1.3 & 0.3 & 0.4 \\
\hline Mean plasma progesterone from d 0 to 14 of the estrous cycle, $\mathrm{ng} / \mathrm{mL}$ & 3.6 & 3.6 & 3.5 & 0.3 & 0.8 & 0.8 \\
\hline
\end{tabular}

${ }^{1} \mathrm{AS}=$ alfalfa silage diet, $\mathrm{BS}=$ barley silage diet, and $\mathrm{SS}=$ barley silage $+4 \%$ starch diet

${ }^{2} P$-value contrast: source $=\mathrm{AS}$ vs. the mean of BS and SS; level $=\mathrm{BS}$ vs. SS.

${ }^{3}$ Estradiol concentration was determined by using the plasma samples collected on d 4, 6, and 8 of the estrous cycle.

${ }^{4}$ Estradiol concentration was determined by using the last 5 plasma samples collected before ovulation. 
(1998) infused starch at $1,500 \mathrm{~g} / \mathrm{d}$ into the rumen or abomasum, milk yield tended to increase, whereas DMI decreased compared with that of cows fed a control diet with no starch infusion. The increase in milk yield in response to starch feeding in the Knowlton et al. (1998) study and the lack of a response in the current study are likely related to the amount of supplemental starch supplied, as Knowlton et al. (1998) supplemented approximately twice as much starch in their study compared with the current study. Additionally, in the Knowlton et al. (1998) study, milk fat, protein, and lactose yields were unaffected by treatment, as observed in the current study. Lactose percentage in the present study was lower in the SS cows compared with the BS cows. This is difficult to explain because we anticipated that the supplemental starch would increase lactose due to its conversion to propionate, glucose, and then ultimately to lactose. In addition, the source of starch fed had no effect on milk yield, milk composition (with the exception of MUN), or DMI, which is in agreement with Khorasani et al. (1993) and Mustafa et al. (2000), where diets of either $50 \%$ barley silage or $50 \%$ alfalfa silage were offered.

The significantly lower MUN with the SS treatment compared with the BS treatment is indicative of better synchrony between energy and protein availability in the rumen; synchrony is important for maximum production of microbial protein (Huntington, 1997). A poor balance between RDP and fermentable carbohydrates results in decreased production of microbial protein and increased absorption of ammonia, which is subsequently converted to urea and deposited into milk (Moharrery, 2004). Low MUN levels are desirable because MUN and circulating levels of urea are correlated and high plasma urea concentrations can be detrimental to oocyte quality (Eicher et al., 1999).

Overall, BCS was not affected by dietary starch concentration, which is in agreement with Gong et al. (2002) who found no treatment differences in BCS after feeding a high starch diet (26\%) compared with a low starch diet (10\%) for $50 \mathrm{~d}$. In contrast, Oba and Allen (2003), in a study using cows at 55 DIM and diets of either 21 or $32 \%$ starch fed for $21 \mathrm{~d}$, found that the change in BCS was positive for cows on the high starch diet, but negative for those on the low starch diet. In the current study, starch source had no effect on BCS, in agreement with Khorasani et al. (1993), who found no difference in BCS when cows were fed an alfalfa silage-based diet versus a barley silage-based diet.

Hormones and metabolites analyzed in this study followed similar patterns postpartum to those reported in previous studies (Doepel et al., 2002; Gong et al., 2002). The decline in glucose concentrations can be attributed to increased demand and uptake of glucose by the mammary gland for lactose synthesis (Leroy et al., 2008), whereas declining insulin levels postpartum have been attributed to nutrient prioritization, specifically to balance glucose supply to tissues of the body during early lactation (Bauman, 2000). The high concentrations of NEFA in the first week postpartum are the result of drastic increases in lipolysis due to increased diversion of nutrients to the mammary glands as NEFA acts as an alternative energy source when glucose needs to be conserved (Leroy et al., 2008).

In contrast to our hypothesis, no treatment differences were observed in plasma concentrations of glucose, IGF-1, insulin, BHBA, or NEFA. This can be attributed to the fact that the 3 diets were similar in net energy concentrations and that DMI was not different among the treatments. Additionally, the difference in starch content among the diets was not as great as anticipated. Our goal was to achieve a $4 \%$ difference in starch content between BS and SS, but this was not attained. Had we achieved the targeted difference, changes in concentrations of the plasma metabolites and hormones may have been evident. For example, Oba and Allen (2003) reported a higher insulin concentration in cows fed a diet containing $32 \%$ starch compared with those fed a diet with $21 \%$ starch. Similarly, Gong et al. (2002) observed an increase in plasma insulin concentrations in cows fed a diet containing $26 \%$ starch on a DM basis compared with one containing $10 \%$ starch. The insulin concentration of cows on the $26 \%$ starch diet was similar to those in the current study and demonstrated a similar pattern over time.

\section{Reproduction}

Dietary supplementation of starch affected certain reproductive parameters of cows in the present study. Particularly, increasing the amount of dietary starch reduced the interval from calving to first ovulation and therefore initiated earlier postpartum cyclicity. However, this beneficial effect was only evident in the SS cows. Gong et al. (2002) found that a greater proportion of cows fed higher levels of starch ovulated before 50 DIM. It is desirable to have cows ovulate early postpartum as this allows them to complete one or more estrous cycles before they are due to be bred (Butler and Smith, 1989). Moreover, the cows ovulating sooner postpartum are those with greater conception rates during the breeding period (Butler, 2000; Ambrose and Colazo, 2007) as these cows are more likely to have normal estrous cycle lengths and more pronounced estrous behavior (Roche, 2006).

Although many factors are correlated with the interval from calving to first ovulation, the fate of the first dominant follicle postpartum appears to regulate this 
event. The ability of the first dominant follicle to ovulate is related to follicle size, LH pulsatility, and IGF-1 concentrations (Roche, 2006). In the present study, the interval from calving to first ovulation tended to be negatively correlated with LH pulsatility, meaning that cows with increased pulsatility at $15 \mathrm{~d}$ postpartum ovulated sooner after calving. This is consistent with the findings of Beam and Butler (1999) in which cows failing to ovulate the first dominant follicle had lower frequency of LH pulses during the first follicular wave postpartum. As well, the length of time to attain a follicle diameter of $10 \mathrm{~mm}$ or greater was positively correlated with the interval from calving to first ovulation. However, no correlation could be made between plasma IGF-1 concentrations and estradiol production or the interval from calving to first ovulation; this differs from results published by Roche (2006) and Beam and Butler (1998), in which IGF-1 was positively correlated with estradiol concentrations during the growth of the first dominant follicle and the ability of this follicle to ovulate. Furthermore, no difference in plasma IGF-1 or insulin concentration was detected among treatments. However, cows fed the SS diet, which was expected to increase circulating concentrations of insulin and IGF1 , ovulated sooner postpartum. That a decrease in the interval from calving to first ovulation could not be attributed to increased plasma insulin concentrations is in agreement with Canfield and Butler (1990), who also found no relationship between insulin concentrations in the first $14 \mathrm{~d}$ postpartum and the interval from calving to first ovulation. Although circulating concentrations of IGF-1 and insulin appeared to have no effect on follicular growth or ovulation rates in the present study, several in vitro studies have identified roles for these hormones in granulosa cell proliferation and estradiol production (Lucy, 2000).

Circulating concentrations of glucose, NEFA, and BHBA were neither affected by treatment nor correlated with the interval from calving to first ovulation. In agreement, Harrison et al. (1990) and Canfield and Butler (1990) found no correlation between these concentrations and interval from calving to first ovulation.

Negative energy balance has also been found to be associated with an increased interval from calving to first ovulation. Beam and Butler (1999) found that an improvement in EB and a shorter interval to EB nadir corresponded to fewer days to ovulation postpartum. More specifically, Butler (2000) found that NEB in the first 3 to 4 wk postpartum was highly correlated with an increased interval from calving to first ovulation. The present study found no correlation between NEB and days to first ovulation and no improvement in EB by increasing the starch content of the diet, thereby not directly supporting our hypothesis. Furthermore,
Canfield and Butler (1990) found that average daily $\mathrm{EB}$ was not correlated with days to first ovulation but that cumulative EB and EB nadir were. In the current study the interval from calving to first ovulation tended to be shorter in cows fed SS (31 d) compared with those fed AS $(43 \mathrm{~d})$ or BS $(38 \mathrm{~d})$ but this reduced interval could not be attributed to an improved hormone profile or to increases in EB or BCS. Nebel and McGilliard (1993) stated that the average interval from calving to first ovulation was $30 \mathrm{~d}$. Similarly, Ambrose and Colazo (2007) reported that the interval to first ovulation after calving averaged $32 \mathrm{~d}$ in a study involving 23 dairy herds, and Colazo et al. (2009) reported calving to first ovulation intervals ranging between 21 and $35 \mathrm{~d}$. Therefore, it may be that the SS cows ovulated within the normal timeframe postpartum, whereas the cows on the other treatments had a delay in first ovulation, possibly due to the lower dietary starch content.

In the current study, BCS was negatively correlated with the anovulatory interval in that the lower the BCS during the first $28 \mathrm{DIM}$, the longer it took for the cow to ovulate. Both the AS and BS cows had a larger numeric decrease in BCS over the treatment period and took longer to ovulate postpartum compared with the SS cows. This finding is in agreement with Beam and Butler (1999) who found that cows losing more BCS had an increased interval from calving to first ovulation.

In the present study a significant percentage of ASand SS-fed cows had double ovulations, with the majority occurring on the first ovulatory event postpartum. Other studies have shown correlations between IGF-1 and the increased incidence of double ovulations and twinning rates. Furthermore, cattle selected for natural twinning were shown to have increased levels of both circulating and follicular IGF-1 (Echternkamp et al., 1990, 2004). As no significant treatment effects were observed for plasma IGF-1 and insulin concentrations, we cannot conclude that increased circulating concentrations of these hormones increased the number of double ovulations in the present study.

Studies examining the effect of increased concentrations of circulating insulin and IGF-1 through diet manipulation have often looked at the effects on the first dominant follicle postpartum and the period to regain cyclicity. The present study examined not only the first ovulation but also monitored one estrous cycle in cows that were at least 45 DIM to determine the effects of IGF-1 and insulin on ovarian dynamics and steroid hormone production later in lactation. No treatment effects could be detected for any of these parameters studied, indicating that increased inclusion of dietary starch was not beneficial beyond the first ovulation postpartum. 


\section{CONCLUSIONS}

In this study, the source of dietary starch, whether it was primarily concentrate or a blend of silage and concentrate, had minimal effects on cow productivity and metabolic and reproductive parameters. Starch supplementation to a barley silage-based diet tended to decrease the interval from calving to first ovulation postpartum, but did not benefit subsequent estrous cycles or fertility. In addition, starch supplementation was not associated with an improvement in EB, metabolic profile, or production parameters.

\section{REFERENCES}

Ambrose, D. J., and M. G. Colazo. 2007. Reproductive status of dairy herds in Alberta: A closer look. Proc. 25th Western Can. Dairy Sem., Advances in Dairy Technology 19:227-244.

Armstrong, D. G., J. G. Gong, and R. Webb. 2003. Interactions between nutrition and ovarian activity in cattle: Physiological, cellular and molecular mechanisms. Reprod. Suppl. 61:403-414.

Armstrong, D. G., T. G. McEvoy, G. Baxter, J. J. Robinson, C. O. Hogg, K. J. Woad, R. Webb, and K. D. Sinclair. 2001. Effect of dietary energy and protein on bovine follicular dynamics and embryo production in vitro: Associations with the ovarian insulin-like growth factor system. Biol. Reprod. 64:1624-1632.

Bauman, D. E. 2000. Regulation of nutrient partitioning during lactation: Homeostasis and homeorhesis revisited. Chapter 18: Pages 311-327 in Ruminant Physiology: Digestion, Metabolism, Growth and Reproduction. CABI Publishing, New York, NY.

Beam, S. W., and W. R. Butler. 1998. Energy balance, metabolic hormones, and early postpartum follicular development in dairy cows fed prilled lipid. J. Dairy Sci. 81:121-131.

Beam, S. W., and W. R. Butler. 1999. Effects of energy balance on follicular development and first ovulation in postpartum dairy cows. J. Reprod. Fertil. Suppl. 54:411-424.

Butler, W. R. 2000. Nutritional interactions with reproductive performance in dairy cattle. Anim. Reprod. Sci. 60-61:449-457.

Butler, W. R. 2001. Nutritional effects on resumption of ovarian cyclicity and conception rate in postpartum dairy cows. Br. Soc. Anim Sci. Occ. Publ. 26:133-145. Br. Soc. Anim. Sci., Penicuik, UK.

Butler, W. R., and R. D. Smith. 1989. Interrelationship between energy balance and postpartum reproductive function in dairy cattle. J. Dairy Sci. 72:767-783.

Canadian Council on Animal Care (CCAC). 1993. Pages 67-69 in Guide to the Care and Use of Experimental Animals. Vol. 1. Canadian Council on Animal Care, Ottawa, Canada.

Canfield, R. W., and W. R. Butler. 1990. Energy balance and pulsatile LH secretion in early postpartum dairy cattle. Domest. Anim. Endocrinol. 7:323-330.

Colazo, M. G., A. Hayirli, L. Doepel, and D. J. Ambrose. 2009. Reproductive performance of dairy cows is influenced by prepartum feed restriction and dietary fatty acid source. J. Dairy Sci. 92:25622571.

Doepel, L., H. Lapierre, and J. J. Kennelly. 2002. Peripartum performance and metabolism of dairy cows in response to prepartum energy and protein intake. J. Dairy Sci. 85:2315-2334.

Echternkamp, S. E., A. J. Roberts, D. D. Lunstra, T. Wise, and L. J. Spicer. 2004. Ovarian follicular development in cattle selected for twin ovulations and births. J. Anim. Sci. 82:459-471.

Echternkamp, S. E., L. J. Spicer, K. E. Gregory, S. F. Canning, and J. M. Hammond. 1990. Concentrations of insulin-like growth factor-1 in blood and ovarian follicular fluid of cattle selected for twins. Biol. Reprod. 43:8-14.

Edmonson, A. J., I. J. Lean, I. D. Weaver, T. Farver, and G. Webster. 1989. Body condition scoring chart for Holstein dairy cows. J. Dairy Sci. 72:68-78.
Eicher, R., E. Bouchard, and M. Bigras-Poulin. 1999. Factors affecting milk urea nitrogen and protein concentration in Quebec dairy cows. Prev. Vet. Med. 39:53-63.

Gong, J. G., W. J. Lee, P. C. Garnsworthy, and R. Webb. 2002. Effect of dietary- induced increases in circulating insulin concentrations during the early postpartum period on reproductive function in dairy cows. Reproduction 123:419-427.

Goodman, R. L., and F. J. Karsch. 1980. Pulsatile secretion of luteinizing hormone: differential suppression by ovarian steroids. Endocrinology 107:1286-1290.

Grant, R. 2005. Optimizing starch concentrations in dairy rations. Pages 73-79 in Proc. Tri-State Dairy Nutr. Conf. Fort Wayne, IN. The Ohio State University, Columbus.

Harrison, R. O., S. P. Ford, J. W. Young, A. J. Conley, and A. E. Freeman. 1990. Increased milk production vs. reproduction and energy status of high producing dairy cows. J. Dairy Sci. 73:2749-2758.

Huntington, G. B. 1997. Starch utilization by ruminants: From basics to the bunk. J. Anim. Sci. 75:852-867.

Khorasani, G. R., E. K. Okine, J. J. Kennelly, and J. H. Helm. 1993. Effect of whole crop cereal grain silage substituted for alfalfa silage on performance of lactating dairy cows. J. Dairy Sci. 76:35363546 .

Knowlton, K. F., T. E. Dawson, B. P. Glenn, G. B. Huntington, and R. A. Erdman. 1998. Glucose metabolism and milk yield of cows infused abomasally or ruminally with starch. J. Dairy Sci. 81:3248-3258.

Leroy, J. L. M. R., T. Vanholder, A. T. M. Van Knegsel, I. GarciaIspierto, and P. E. J. Bols. 2008. Nutrient prioritization in dairy cows early postpartum: Mismatch between metabolism and fertility. Reprod. Domest. Anim. 43:96-103.

Lucy, M. C. 2000. Regulation of ovarian follicular growth by somatotropin and insulin-like growth factors in cattle. J. Dairy Sci. 83:1635-1647.

Lucy, M. C. 2001. Reproductive loss in high-producing dairy cattle: Where will it end? J. Dairy Sci. 84:1277-1293.

Martínez, M. F., J. P. Kastelic, G. A. Bó, M. Caccia, and R. J. Mapletoft. 2005. Effects of oestradiol and some of its esters on gonadotrophin release and ovarian follicular dynamics in CIDR-treated beef cattle. Anim. Reprod. Sci. 86:37-52.

Moharrery, A. 2004. Investigation of different levels of RDP in the rations of lactating cows and their effects on MUN, BUN and urinary $\mathrm{N}$ excretion. Ital. J. Anim. Sci. 3:157-165.

Mustafa, A. F., D. A. Christensen, and J. J. McKinnon. 2000. Effects of pea, barley, and alfalfa silage on ruminal nutrient degradability and performance of dairy cows. J. Dairy Sci. 83:2859-2865.

NRC. 2001. Nutrient Requirement of Dairy Cattle. 7th rev. ed. Natl. Acad. Sci., Washington, DC.

Nebel, R. L., and M. L. McGilliard. 1993. Interactions of high milk yield and reproductive performance of dairy cows. J. Dairy Sci. 76:3257-3268.

Novak, S., B. K. Treacy, F. R. Almeida, J. Mao, W. C. Buhi, W. T. Dixon, and G. R. Foxcroft. 2002. Regulation of IGF-1 and porcine oviductal secretory protein (pOSP) secretion into the pig oviduct in the per-ovulatory period, and effects of previous nutrition. Reprod. Nutr. Dev. 42:355-372.

Oba, M., and M. S. Allen. 2003. Effects of corn grain conservation method on feeding behavior and productivity of lactating dairy cows at two dietary starch concentrations. J. Dairy Sci. 86:174183.

Pierson, R. A., and O. J. Ginther. 1984. Ultrasonography of the bovine ovary. Theriogenology 21:495-504.

Raabo, E., and T. C. Terkildsen. 1960. On the enzymatic determination of blood glucose. Scand. J. Clin. Lab. Invest. 12:402-407.

Rawlings, N. C., and A. C. O. Evans. 1995. Androgen negative feedback during the early rise in LH secretion in bull calves. J. Endocrinol. 145:243-249.

Roche, J. F. 2006. The effect of nutritional management of the dairy cow on reproductive efficiency. Anim. Reprod. Sci. 96:282-296.

SAS Institute. 2002. SAS User's Guide: Statistics. Version 9.1 for Windows. SAS Institute Inc., Cary, NC. 
Silveira, C., M. Oba, W. Z. Zang, and K. A. Beauchemin. 2007. Selection of barley grain affects ruminal fermentation, starch digestibility, and productivity of lactating dairy cows. J. Dairy Sci. 90:2860-2869

Spicer, L. J., and S. E. Echternkamp. 1995. The ovarian insulin and insulin-like growth factor system with an emphasis on domestic animals. Domest. Anim. Endocrinol. 12:223-245.

Van Soest, P. J., J. B. Robertson, and B. A. Lewis. 1991. Methods for dietary fiber, neutral detergent fiber and non-starch polysaccharide in relation to animal nutrition. J. Dairy Sci. 74:3583-3597.
Williamson, D. H., and J. Mellanby. 1974. D-(-)-3-Hydroxybutyrate. Page 1836 in Methods of Enzymatic Analysis. Vol. IV. H. U. Bergmeyer, ed. Academic Press, New York, NY.

Zalkovic, P., M. A. MacLean, and D. J. Ambrose. 2001. A simple procedure to secure an indwelling jugular vein catheter to the neck of cattle for repeated blood sampling. Can. Vet. J. 42:940-942. 